\title{
Reconstruction from the aspects of Islamic law in corporate zakat accounting
}

\author{
Irfan $^{1 *}$, Muhyarsyah ${ }^{2}$, Arif Pratama Marpaung ${ }^{3}$, Ina Liswanty $^{4}$ \\ ${ }^{1,3}$ Faculty of Economics and Business, Universitas Muhammadiyah Sumatera Utara, Medan, Indonesia \\ ${ }^{2}$ Faculty of Economics and Business, Universitas Mercu Buana, Jakarta, Indonesia \\ ${ }^{4}$ Faculty of Economics and Business, Universitas Potensi Utama, Medan, Indonesia \\ ${ }^{*}$ Corresponding author email: irfanumsu@gmail.com
}

\section{A R T I C LE IN FO}

Article history:

Available online

Keywords:

Islam, corporate zakat, Accounting standards

DOI:

https://doi.org/10.20885/jaai.vol24.is s2.art7

\section{A B S T R A C T}

This research aims to explore the concept of corporate zakat accounting from the aspects of Islamic law as the basis to determine muzakki (zakat payer) and legally mandate companies to pay zakat. This is a qualitative research with the data obtained through a literature study by exploring various classical and contemporary sources using historical, analytical, and critical tools. The research also examined the concepts of figh and sharia in economic activities. This study found that companies were synonymous to syirkah in terms of a spiritual entity with the inherent traits in humans as the right to accept and fulfil the responsibilities. Consequently, companies are mandated to pay zakat based on the five principles of muzakki with the calculations carried out using the corporate zakat accounting method based on the established standards. This process positively assists companies in the realization of a fair and equitable distribution of wealth, as well as in the emergence of corporate social responsibility collectively and individually.

\section{Introduction}

The implementation of mu'amalah in economic activities leads to significant developments, in terms of form, type, model, and method of application. This condition certainly needs to be reconstructed against various fiqh concepts in Islamic thought to produce an elaborated timeframe and place that do not conflict with the values of aqeedah, sharia, morals, and shak or zhann (still uncertain). The discourse on zakat and its calculation in the academic environment continues to develop although people no longer feel that it is only limited to the realm of studies and discourse on religion or sharia. Rather, it has been widened to include the issue of social economics (Adnan \& Bakar, 2009).

Islamic scholars have discussed the problem of reconstructing Islamic thought in mu'amalah activities. Iqbal (1934) carried out the research on the reconstruction of fiqh (jurisprudence) which was considered as an absolute doctrine due to the closure of ijtihad. Therefore, changes in the modernization of social life to reconstruct fiqh can be conducted by legal experts with the capability to encourage reconciliation as well as the social reformation of Islamic norms and laws (Zaidi, 2006).

The empirical data of Islamic accounting system in the Umayyad leadership era in Andalusia, Abbasid, Abi Hafsh in Ifriqiyah, Zanatah in Maghribi, Turkey, Iraq, Persia, and Syria, were associated with various models. However, the similarities were in the universal values of Islam, with the locality associated with daulah or caliphate, with the accounting model adapted to the developing culture (Mulawarman et al., 2011). Majid (1997) states that the role and function of Islamic accountants, generally called Diwan, consisted of the characteristics that are adjusted to their leaderships.

Muslim scholars have compiled various thoughts associated with fiqh of mu'amalah, especially in the issue of zakat with new insights and enlightenment in mu'amalah activities, especially in the economic aspects and in the understanding of corporate zakat. However, the studies on fiqh mu'amalah in the context of zakat have not been specifically arranged although the efforts to understand companies as zakat objects were written by Qaradawi (2014), De Zayas (2008), and Obaidullah (2016). Since there are limited discussions regarding corporate zakat, especially its implementation using zakat accounting, an in-depth study is needed by reconstructing the concept of fiqh at the level of ijtihad. This aims to ensure the provision of new ideas in mu'amalah figh in order to provide a comprehensive solution to issues associated with zakat using accounting calculation from the perspective of fiqh and sharia. Therefore, this research aims to explore the concept of companies from the aspects of Islamic law and sharia as the basis to determine it as muzakki, thereby raising their legal obligation to pay zakat through the accounting calculation method. 


\section{Literature Review}

\section{Company as a Subject of Zakat}

Zakat has become an essential instrument in the process of distributing wealth among Muslims. In principle, the collection and distribution of charity are independently carried out by an Islamic jurist with/without legal entity. This is because the country only functions as a regulator in maximizing the activities of charity institutions. Therefore, the payment of zakat arises from the consciousness of human beings to fulfil their obligations to Allah in accordance with shariah values. Zakat is considered worship of mahdhah and ghdh mahdhah because it covers fitrah and mal. The payment of zakat is not only an obligation of a Muslim to the community and country, rather it is mandated by Allah's command. According to Lewis (2001), charity is not only related to donations, but also to its emphasis on rights and claims. Rahim (2003), states that Muslim companies are obligated to pay zakat as their contribution to social welfare in order to fulfill their responsibility to Allah Almighty and their surrounding communities.

Zakat is one of the basic principles of Islam that has a bearing on the accounting system. According to Lewis (2001), an individual's wealth needs to be calculated in quantitative value. Therefore, the calculation is necessary to conduct using accounting in the Islamic perspective, which according to Haniffa and Hudaib (2001) is a guarantee function aimed at upholding social justice through procedures, routines, objective measurements, oversight and formal reporting in accordance with Islamic principles. Companies as muzakki are obligated to pay zakat, which is a compulsory charity. This is carried out in accordance with the condition of the muzakki and the property of zakat.

The process of calculating zakat using accounting method refers to the basic rules that are used as a concept in determining corporate zakat. Implementing a fair accounting method and reporting system ensures equitable redistribution of wealth and income through zakat payments (Badshah et al., 2013).

\section{Company as A Muzakki in the Figh Perspective}

In Islam, property is expended in accordance with Allah's rule and through zakat payment, which works for selfpurification. In addition to the Quran, the Hadith also provides examples of the obligations and regulations for issuing zakat.

Islam encourages every Muslim, both personal and corporate, to practice charity. In Indonesian law, among the objects from which zakat is required to issue are trade and enterprise activities. It can be emphasized that company can be classified as a party obligated to pay zakat and attached on it the connotation as a muzakki. Zakat is no longer limited to individual muzakki, rather, it is a subject with the understanding extended to institution (Adnan \& Bakar, 2009).

Companies run by Islamic principles are obligated to pay zakat in fulfilling their obligations as a shakhshiyyah i'tibariyyah, which is not only confined to Sharia awareness and faith, but also serves as a contribution to social well-being and fulfils social and absolute responsibilities to God (Hidayat, 2013; Mas'udi, 1993; Qahf, 2009; Rahim, 2003). Company is obligated to pay zakat over all the valuables through zakat ability or wealth with the basic principle based on the merchandise ('Urud al-tijarah) which is acquired for the purpose of trading for profit (Bakar, 2007).

According to Al-Husaini (1997) the two obligatory requirements of zakat related to muzakki, are Islam and independent (not being a slave). Furthermore, Al-Zuhaili (1997) added two more conditions, namely baligh and logic. Qaradawi (2014) stated that there were six obligatory zakat requirements related to property, namely full, growing, reasonably priced, more than ordinary, debt-free, and valid in one-year (hauh).

Muzakki does not automatically provide oneself with the obligation to issue zakat, rather the obligation arises when the conditions of the property are fulfilled. Therefore, in order to establish a zakat obligation, one needs to consider the conditions of the muzakki and the property. According to Qaradawi (2014), there are six principles of zakat rules and conditions that can be used to formulate the characteristics of a muzakki as the person or persons required to make payment. These six principles are (1) confidence, (2) justice, (3) productivity (haul), (4) reasoning, (5) convenience, and (6) freedom (independence). Meanwhile, Al-Zuhaili (1997) states that there are six requirements of muzakki subject to zakat, namely (1) Islam, (2) Baligh-minded, (3) Free or independent, (4) Owning property until nisab and haul, (5) Full ownership (al-milkiyah at-tammah), and (6) meeting basic requirements before making payment.

The questions associated with this research are as follows. Firstly, since Muslim are mandated to be muzzaki, what happens to the unbelievers living in a Muslim country, children and crazy people, as well as slaves, in terms of compulsory requirements to fulfil the obligation to pay charity. Secondly, why was the ownership of property more individual in the past, while in modern times many are collectively in the forms of corporation, foundation, cooperative, and whichever form subject to zakat. 
In terms of Muslim muzakki, the jurisprudence sets out zakat obligation for Muslims alone. This is because that it is one of the pillars of Islam, and therefore it is not obligated to unbelievers. However, Umar Bin Khatab stated that this statement raised a number of questions from several second-generation people saying that zakat could be performed to the infidels of zimmi. The questions were around that if the unbelievers received zakat, then why Muslims did not receive zakat from the rich among them. Qaradawi (2014) stated that there was no reason not to collect zakat from the infidels, in view of the obligation and use as a monetized as tax from non-Muslims (Kafir zimmi).

With regard to the conditions of puberty and the intellect, Imam Abu Hanifah states that it is not obligatory to pay alms to children and crazy people, since charity includes worship offered to adults, in addition to prayer, fasting and pilgrimage. However, Imam Hanafi obligates zakat for young men and women. This means that their ability to meet the requirements of zakat (adequacy), needs to be paid by their guardian. Furthermore, the intentions of children or madmen cannot be accounted for in worship because they do not belong to the mukallaf (Ashshiddiq, 1980). Jumhur scholars believe that children are not only obligated to tithe, they also need to be provided with alms through charity. This hadith has made it clear that the orphan's property is still obligated to charity, in accordance with Aisha's research regarding the provision of zakat to an orphanage. Slaves are not obligated to accept zakat because they have no legal ability, such as ownership rights and not entitled to any transaction. Scholars stated that slaves were significantly great gifts for their employers. Hanafi and Shafi'i stated that it was compulsory that zakat to be issued for the slaves, however Maliki and Ahmad, objected to their opinion (Ashshiddiq, 1980). The second issue, on whether or not a company is obligated to issue zakat, was answered in the first International Proceedings of the charity in Kuwait on 3 April 1984. The proceedings stated that companies were obligated to issue zakat due to their existence as the legal entities. According to the muktamar, a company is either a syakhsan i'tibaran (a legal entity considered by the people) or a hukmiyyah syakhshiyyah. Therefore, they are included as muzakki or zakat subject (Hafidhuddin, 2002).

\section{Principles of Corporate Zakat Accounting}

Based on the thinking exploratory results presented in the literature study and the various principles put forward by the researchers, the accounting for corporate zakat can be summarized in five main principles, namely 1). Ownership is dominated by individuals or groups of Muslims, 2). Business needs to be lawful, 3). Company's assets can be valued, 4). The company's assets can grow, and 5). The minimum company wealth is 85 grams of gold.

\section{Ownership Owned by Muslims}

Ownership in Islam is in accordance with religious values, Sharia rules (Djakfar, 2012; Hasanah, 2010; Tariqi, 2004). Human property is, in fact, the property of Allah SWT, and not an absolute possession of man (Djakfar, 2007; Lubis, 2000). Ownership in Islam is divided into three, namely 1) individual, 2) public, and 3) state (Djakfar, 2012; Hafidhuddin, 2002). This is a condition that has been established by Islamic scholars in the matter of paying the zakat by reference (al-milkut taka).

God created man as caliph on earth, therefore, men are blessed with the right of ownership (milikiyyah) over the property (mall) in order to enable them lawfully carry out their duties and obligations in the family, community, and to God (Kameel et al., 2006). The examples related to one of the ownerships is financial assets, such as currency and exchangeable assets, which can be the subject of charity, used to replace gold and silver as intermediaries (tools) in exchange and value-saving (Rahman, 2015).

Ownership is essentially a person's full power to utilize his property through various means and in accordance with the rules and conditions of Allah Almighty. Similarly, in the above provisions, the ownership of property required to be practised is only the property of a Muslim as described in terms of muzakki. Therefore, companies that are wholly owned by Muslim entrepreneurs are obligated to pay zakat in their honour.

If the employees of a cooperative (syirkah) are all Muslims, zakat is issued before the dividend is distributed to the corresponding parties. However, if the people involved include non-Muslim, zakat is only issued for the Muslims assuming that the number exceeds nisab (Purwanto \& Sukmono, 2009). However, in reference to Qaradawi (2014) by viewing dzimmi infidelity, the corporate zakat expenditure can be made entirely without distinguishing the religious background of the people running the cooperation (syirkah), with the interpretation that the charity is issued by one company as zakat and the other, as tax.

\section{Fields of Mandatory Laws}

Muslims are obliged to seek and trade through halal business transactions in accordance with Islamic sharia. This can be analyzed from two aspects, namely, the objectivity of the object which is transacted and the refinement in a transactional process (Wiyono, 2005). In addition to halal property, the business should not raise any doubt (syubhat), either in its indications (qara'in), consequences (lawahiq), causes (sawabiq), substitutes, exchanges, or 
payments (Ghazali, 1997). The halal property of trading products and commodities is an absolute Islamic tradition. Its existence is a boon to Sharia economic system and different from the conventional economy. Halal for Muslims is a fundamental ideology and necessity, while for non-Muslims, it is a protection against anything that can harm the individuals and society.

Charity obligation, product, and commodity legalization are closely linked and united. Therefore, this is not overlooked for a number of reasons since zakat is the worship and consumption of halal commodities. Secondly, zakat is intended for life and halal is the protection of human life, therefore, the imposition of zakat on company is in order that the products and commodities produced will not cause harm and danger to human life. Therefore, people feel safe in consuming the product. Third, zakat is impossible without an ownership of property and ownership that is not legal according to Islam, which is not halal. Therefore, the zakat determination on the company needs to be based on the ownership obtained through the process authorized by Allah SWT. It can be concluded that corporate zakat is only derived from halal products.

According to Hafidhuddin (2002), the property needs to be obtained in a good and lawful way, meaning that the illegal, substantive property of the master or the means of obtaining it is not subject to zakat because it will not accepted by Allah Almighty. Companies that engage in illegal properties, such as alcohol, pigs, and gambling, are not subject to the provisions of the subject of zakat.

\section{Acceptable Company Assets}

Qudamah (1986) defined selling as the exchange of property between two or more people. Zuhaily (2007) states that it is the process of exchanging something with another by transferring ownership (Sabiq, 2006). Selling is the most important source of sustenance in human life as put forth by Prophet Muhammad. Meanwhile, in terms of fiqh, valuable things cannot be traded, therefore zakat is not issued. The company's assets need to be assessed for the amount of zakat that needs to be issued. Therefore, without the valuation of assets, zakat rate cannot be calculated. In principle, the property is paid for by the charity, and the value needs to reach the nisab, more than the basic necessities. Additionally, the property needs to be free of debt and fully owned by the owner. However, while muzakki is an institution with various asset classifications, liabilities, and business activities, zakat calculation method also appears to vary with the aim of generating optimal payment (Farhan \& Triyuwono, 2012).

\section{Company Assets which can Grow}

The development of a company's assets is defined as the incremental value of a product and a commodity. The development also includes current and non-current assets (fixed assets). Therefore, in calculating zakat, a company should pay based on its current assets. A property develops when it is able to generate income, profit, or additional value. Generally, growth occurs through business outcomes; therefore, property that cannot grow is not obligated to zakat. This immovable property is usually for personal use such as house, vehicle, furniture, etc (Majid, 2003; Qaradawi, 2014; Sahata, 2003).

The properties charged for zakat are those that develop or have the potential to grow and generate profit. The condition of the developing property is based on the assets imposed at the time of the Prophet, which was relatively fertile, such as livestock raised from agricultural produce, gold, silver, money and business goods (Majid, 2003). The settlement of zakat-based property is also through actions taken to generate income and profit. The components of the productive property are presented through cash, non-cash financial instruments, inventory of final goods, fixed assets of a company, net trade receivables, property management, and long-term assets.

\section{Corporate Minimum Wealth Standard Equivalent to 85 Grams of Gold}

The minimum standard of wealth ownership is not something new in the context of charity. However, in classical figh literature, the wealth for zakat needs to meet nisab. The majority of scholars have converted into the value of 20 dinars (based on the gold coin at $4.25 \mathrm{grams} /$ dinar). This is the highest amount of nisab in zakat for the owners whose wealth that goes beyond the basic needs of a person. The companies with assets of less than 85 grams of gold are not required to pay zakat and do not include the wealth they deserve. In addition to the five principles of zakat accounting previously presented, in accordance with the International Proof of Accountability in Kuwait, other technical requirements are as follows:

Firstly, some laws or regulations mandate companies to issue zakat. In the time of the Messenger of Allah, the payment was determined by the governmental authority, and those that refused to pay got their property confiscated. Similarly, after the death of the Messenger of Allah, Abu Bakr as-Siddiq stated that the government and the state was responsible for restoring the obedience of a group of people that refused to pay zakat. Secondly, the law of corporate establishment (Basic Budget and Household Budget) indicates that state matters are related to the corporate zakat expenditure. This means that the internal rules can only be implemented when there are the 
collective consciousness and desire of the corporate managers to issue corporate zakat. This means that internal factors do not prevent the companies from issuing zakat when interacting with the rules.

Thirdly, General Meeting of Shareholders (AGMs) held by the company can provide a recommendation obligating the company to expend zakat. This needs to be supported by all members of the meeting in order to instill a high level of awareness and spirit in carrying out the religious practices as the corporate charity. Furthermore, the shareholders need to be aware that there are other people who are entitled to their wealth and of ensuring that the corporate zakat positively impacts their corporate existence and development.

\section{Research Method}

This study uses a descriptive method to describe the concepts of figh and sharia in economic activities. This method is useful to explain the common phenomena and their associating relationships. According to Kothari (2004), descriptive research is used to accurately portray the characteristics of a particular individual or the situation of a group. Kothari further states that this type of study can be used to describe a situation and analyze it to produce a critical evaluation.

The secondary data of this study were obtained from the previous literatures related to corporate as muzakki, Islamic law, and use of zakat as an accounting calculation method. This study also uses qualitative methods with historical, analytical and critical tools to obtain data by exploring various classical and contemporary sources. Some of the previous studies used in explaining zakat accounting were carried out by Owoyemi (2020), Asni (2019), Saad, et al. (2020), and Adnan and Bakar (2009).

\section{Results and Discussion}

Humans bring about new types of zakat that are in line with sharia values and not contradictory with the requirements of figh. Therefore, zakat is no longer seen solely as being limited to the scope of religious or sharia studies and discussions, rather it has grown and embraced economic and social issues (Adnan \& Bakar, 2009). The accounting standards broadly refer to the guidelines that various institutions have developed and established. The institutions set the standards to implement accounting and reporting systems related to financial issues. Currently, several accounting regulatory bodies have issued the guidelines for preparing reports. Some institutions included involve Accounting and Auditing Organization for Islamic Financial Institutions (AAOIFI), Malaysian Accounting Standard Board (MASB), and Indonesian Association of Accountants (IAI) (Adnan \& Bakar, 2009).

Furthermore, Many institutions have now used as company as a legal entity (shakhiyah i'tibariyah) as the basis for calculating corporate zakat and not only referred to as a personal obligation of the company's owner. According to Hafidhuddin (1998), if a company has gained and enjoyed its business benefits, its obligation to pay zakat applies. Every Muslim that carries out trade activities either individually or in federation, through mining, logging, manufacturing, carpentry, wholesale trading, transportation, housing and grocery business is included in zakat compulsory process. The conditions of the nisab and haul are subject to 354 days of Qamariah year (lunar calendar) (Hassan, 1986). Thus, zakat needs to be based on the wealth generated from the profits through business activities.

Each company has at least three types of assets. The first is a property in the form of goods like facilities, infrastructure, as well as business commodities. The second property is that in cash, which is usually saved in a bank. The last is in the form of debt. Business properties that are required to be taxed are those three forms of properties, excluding infrastructure and other urgent obligations, such as payables (Hafidhuddin, 2007). However, in corporate zakat, the charity also needs to be seen from the existence of the person that performs the syirkah (cooperation). Therefore, assuming that all those performing the syirkah are Muslim, it is important to issue zakat first before distributing the benefits. However, if the syirkah is run by non-Muslim, zakat is released only for the Muslim employees (Purwanto \& Sukmono, 2009).

Corporate zakat needs to be imposed on the working capital of a company, not only on the business items. When a company is to issue zakat, it needs to calculate the amount of money the company possesses and the value of the merchandise. The company also has to count the whole items in cash, debts (agreed to pay), and deduct the debts to be paid from zakat (Salam, 1991).

The above explanations provide a description that corporate zakat calculation needs to be based on financial balance sheet report by reducing the liability on current assets. Similarly, all properties, excluding infrastructure, e-payment of debts, and other obligations, are added to profit to obtain zakat worth of $2.5 \%$. Meanwhile, there are other assumptions suggest that corporate zakat is imposed only on the profitable properties. The difference in the context of determining zakat that company must expend results from the jurisprudence of fiqh scholars and academics. The differences certainly have their own legal bases in providing a valid argument to make a decision on zakat-based company property. There is no fundamental difference between the scholars of the figh and the contemporary academics regarding the obligation of the company to issue zakat. Therefore, the reconstruction in the corporate zakat arrangement made by the contemporary fiqh scholars and Islamic academics 
has increased the proficiency of Islamic scholars, especially in the economic activity. The reconstruction of the classical fiqh does not change the essence of the qath'i, rather it adapts to the current development of socioeconomic conditions. Therefore, the issue of dzannican be debated and developed as opposed to the sources of the Qur'an and the Hadith.

The enterprise zakat is equal to the business value of $2.5 \%$, based on the haul using qomariah year (lunar calendar). However, companies need to adjust the zakat value in the biennial year. In the zakat mira of $1984 \mathrm{M} /$ $1404 \mathrm{H}$ it was agreed that the religious year was longer than the qomariah year by eleven days. Therefore, the users of Sharia year need to be able to take into account these differences in setting up the company's time for zakat issuance. This is because the use of yearly average (365 days) has a direct relation to the value of corporate zakat of $2.578 \%$ resulting from $2.5 \%$ X $365 / 354$, therefore $2.5 \%$ is not utilized.

There three elements that are central to making corporate zakat estimate, those are cash, readiness to trade, and debts. The corporate zakat calculation pattern as referred to in al-Amwaal's book concludes that the balance sheet report is the current assets minus the current liabilities. This means of calculation is commonly referred to as Sharia or Net Assets method, and used in United Arab Emirate and several other Islamic countries to perform corporate zakat assessments.

In determining and evaluating Sharia-compliant zakat or property, Salam (1991) stated that zakat was imposed on a company's current assets. Table 1 shows the sequential steps used to calculate a company's assets.

Table 1. Company Assets

\begin{tabular}{ll}
\hline Current asset type & \multicolumn{1}{c}{ Requirements and Adjustments Required } \\
\hline Cash & Subject to zakat \\
Bank saving & Subject to zakat after deducting the interest \\
Temporary investment & Subject to zakat at a market value \\
Account not yet received. & $\begin{array}{l}\text { Subject to zakat unless truly non-billable } \\
\text { Inventory }\end{array}$ \\
& $\begin{array}{l}\text { All supplies in warehouses, showrooms, on the streets, distributed in the form of } \\
\text { consignment, finished and produced goods, and raw materials are subject to zakat and } \\
\text { valued at market prices. This is in accordance with the meaning of the hadith narrated by } \\
\text { Jabir bin Zaid which stated that, "When the obligation of zakat falls, it is removed." }\end{array}$ \\
Equipment & $\begin{array}{l}\text { Equipment subject to zakat is a component of goods produced and not classified as } \\
\text { "qoniyyah." The value used is the market price. } \\
\text { Shopping pay first }\end{array}$ \\
Source: Results processed, 2018 &
\end{tabular}

The fixed assets of a company are not included in the zakat-related property because the Prophet (s) ordered the removal on any property which was ready for sale. Based on Salam's (1991) earlier opinion, the scholars have concluded that deducting liabilities from assets indicates that zakat on a company is a current liability. In accordance with any zakat-charged property, the source of data used to determine and assess the deductible liability of the zakat-taxed property is the financial balance with corporate liability, as shown in Table 2.

Table 2. Corporate Liability

\begin{tabular}{|c|c|}
\hline Current Liability Type & Requirements and Adjustments Required \\
\hline Trade liability & As a subtraction with the book value \\
\hline Promissory note & As a subtraction with the nominal value \\
\hline Due liability & As a subtraction with the book value \\
\hline Tax liability & as a deduction without the addition of fines or interest \\
\hline \multirow[t]{4}{*}{ Advance paid income } & $\begin{array}{l}\text { The value is calculated based on the value recorded in the contract without addition or } \\
\text { subtraction. }\end{array}$ \\
\hline & As for its legal provisions, the followings are distinguished. \\
\hline & $\begin{array}{l}\text { 1. If the income received is in proportion to the price of undelivered goods, then it is not } \\
\text { included in the zakat-charged property, therefore cannot be deducted. However, if the } \\
\text { goods are included in the zakat-rich property, they are deducted. }\end{array}$ \\
\hline & $\begin{array}{l}\text { 2. If the income received is a payment for the services that have not been provided, it includes } \\
\text { a reduction in the value of the zakat. }\end{array}$ \\
\hline Long-term due obligations & As a subtraction with the book value \\
\hline Liability Interest & As a subtraction \\
\hline
\end{tabular}

The various methods used to assess the zakat of a company were described by Harahap (1997) as indicated by Qaradawi (2014) and Hafidhuddin (1998). This method consists of different assessment techniques and calculations which are obtained from financial statements, such as balance sheet as well as profit and loss reports. The standard does not only apply to the methods used by companies to calculate zakat-based corporate property, 
but also certainly causes differences in the methods in accordance with the individuals and companies. Furthermore, charity institutions also make differences in corporate zakat calculations. Some methods for performing zakat calculation applied in Indonesia are shown in Table 3.

Table 3. Zakat accounting calculation methods

\begin{tabular}{|c|c|c|}
\hline Standard Formulation & Zakat Rate & Basis of Estimation \\
\hline T.E Gambling \& Karim & $2,5 \%$ & $\{($ Capital + Reserves - Fixed assets $)+$ Net Profit $\} \times 2,5 \%$ \\
\hline Yusuf al-Qardhawi & $2,5 \%$ & (Capital + net profit) $\times 2,5 \%+($ net asset profit $\times 10 \%)$ \\
\hline Bazis DKI & $2,5 \%$ & (capital + net profit) $\times 25 \%+($ net asset profit $\times 10 \%)$ \\
\hline Syariat Takful Malaysia Berhand & $2,5 \%$ & Profit before zakat and tax x 2,5\% \\
\hline Bank Muamalat Indonesia & $2,5 \%$ & Profit before tax $\times 2.5 \%$ \\
\hline Didin Hafidhuddin & $2,5 \%$ & $\begin{array}{l}\{(\text { total the net of current assets }+ \text { net profit)-current liability }\} \times 2,5 \\
\%\end{array}$ \\
\hline Muhammad Kamal Atiyah & $\begin{array}{l}2.5 \% \text { of current } \\
\text { assets and } 10 \% \text { of } \\
\text { fixed assets }\end{array}$ & $\begin{array}{l}\text { Changed assets (capital }+ \text { net profit) } \times 2.5 \% \\
\text { Fixed assets profit, fixed assets } \times 10 \%\end{array}$ \\
\hline Qanun N0. 7 year 2004 & $2,5 \%$ & Profits that reach the nisab within 1 year $\times 2.5 \%$ \\
\hline AAOIFI & $\begin{array}{l}2.5 \% \text { (Hijriah) or } \\
2.5775 \% \text { (Masehi) }\end{array}$ & $\begin{array}{l}\text { Net Investment Fund Method = paid-up capital }+ \text { excess deductions } \\
\text { from assets + profit earned + net income }+ \text { unpaid liabilities at the } \\
\text { end of the loan repayment year - (value of fixed assets }+ \text { unnecessary } \\
\text { investments such as farm to rent }+ \text { accumulated losses). } \\
\text { Net Current Asset Method = assets - liabilities }+/ \text { - adjustments. }\end{array}$ \\
\hline
\end{tabular}

Source: Harahap (1997)

\section{Conclusion}

Islam is a religion of guidance given by Allah Almighty to the Prophet Muhammad, and the teachings consist of three basic foundations, namely aqidah, sharia, and morality. These foundations can be implemented in Islamic economic activities using the Qur'an, Hadith, and ljtihad. However, the development of forms, types, models and methods of the economic activities need a reconstruction of the concept of figh through the conception of time and place, as opposed to the values of faith, sharia, and morality. This process can be conducted by setting up a company as a subject of zakat. In the classical study of figh, it was unable to perform corporate charity. However, in the past companies were introduced like shirkah, with more or less people working together for profit, thereby obligating them to pay zakat. Its essence is the syakhshiyyah i'tibariyyah (spritual entity) or the syakhshiyyah hukmiyyah which is referred to as al-dhimmah or a trait attached to human beings, namely ahliyah al wujud (right to receive) and ahliyyah al-ada (right to discharge responsibility).

Furthermore, the position of a company can be set as a muzakki in the subject of zakat based on five principles, namely Muslim-owned ownership, halal business, evaluatable enterprise assets, growing enterprise assets, and company's minimum wealth worth 85 grams of gold, as well as other technical requirements. The companies can evaluate zakat through the zakat accounting calculation method issued by various Islamic institutions such as Accounting and Auditing Organization for Islamic Financial Institutions (AAOIFI), Malaysian Accounting Standard Board (MASB), and Indonesian Accounting Association (IAI). However, the problems arise due to differences in the corporate zakat calculations set by each accounting standards institution which result in various zakat obligations paid by the companies. However, fundamentally, the company's obligation to pay zakat has been agreed upon by Islamic scholars and in the study of contemporary fiqh. Therefore, the extent to which zakat obligations paid by companies in performing corporate zakat calculations can be legally recognized in accounting institutions.

\section{References}

Adnan, M. A., \& Bakar, N. B. A. (2009). Accounting treatment for corporate zakat: a critical review. International Journal of Islamic and Middle Eastern Finance and Management, 2(1), 32-45. https://doi.org/10.1108/17538390910946258

Al-Husaini, A.-I. T. A. B. (1997). Kifayatul Akhyar Fii Alli Ghaayatil Ikhtishaar (Muhammad (ed.); ke 1). Bina Ilmu. Al-Zuhaili, W. (1997). Al-Fiqh al-Islami wa Adillatuh Jilid IV. Dar Al-Fikr.

Ash-shiddiq, H. (1980). Pengantar Hukum Islam. PT. Bulan Bintang.

Asni, F. (2019). Management of fatwa standardisation on the practice of bay' 'inah contract in Malaysia: an analysis according to usul al-Fiqh and mura'aht al-Khilaf method. Qualitative Research in Financial Markets. 
https://doi.org/10.1108/QRFM-07-2019-0084

Badshah, I., Mellemvik, F., \& Timoshenko, K. (2013). Accounting From A Religious Perspective: A Case of The Central Government Accounting In Islamic Republic of Pakistan. Asian Economic and Financial Review, 3(2), 243-258.

Bakar, N. B. A. (2007). A Zakat Accounting Standard (ZAS) for Malaysian Companies. The American Journal of Islamic Social Sciences, 24(4), 74-92.

De Zayas, F. G. (2008). The Law Institution of Zakat. Islamic Book Trust.

Djakfar, M. (2007). Etika Bisnis Dalam Perspektif Islam. UIN-Maliki Press.

Djakfar, M. (2012). Etika Bisnis : Menangkap Spirit Ajaran Langit dan Pesan Moral Ajaran Bumi. Niaga Swadaya.

Farhan, A., \& Triyuwono, I. (2012). Metode perhitungan zakat perusahaan pada CV. Minakjinggo. Jurnal IImiah Mahasiswa FEB, 1(2), 1-26.

Ghazali, A. H. Al. (1997). Al-Wajiz fi Fiqh Mazhabil Imam asy-Syafi'i. Darul Arqom.

Hafidhuddin, D. (1998). Zakat Infak Sedekah. Gema Insani.

Hafidhuddin, D. (2002). Zakat dalam Perekonomian Modern. Gema Insani.

Hafidhuddin, D. (2007). Agar Harta Berkah dan Bertambah. Gema Insani.

Haniffa, R. M., \& Hudaib, M. A. (2001). A Theoretical Framework for the Development of the Islamic Perspective of Accounting. Accounting, Commerce \& Finance: The Islamic Perspective International Conference, 141.

Harahap, S. S. (1997). Akuntansi Islam. Bumi Aksara.

Hasanah, U. (2010). Manajemen Zakat Modern: Instrumen Pemberdayaan Ekonomi Umat (UNSPECIFIED (ed.)). UIN-Maliki Press.

Hassan, M. S. (1986). Zakat dan Cukai Pendapatan di Malaysia. Persekutuan dan Persatuan Ulamak Malaysia.

Hidayat, F. (2013). Zakat Hasil Pertanian Kontemporer. Nurani, 13(2), 51-60.

Iqbal, M. (1934). The Reconstruction of Religious Thought in Islam. Oxford University Press.

Kameel, A., Meera, M., \& Larbani, M. (2006). Seigniorage of fiat money and the Maqasid al-Shari'ah: The compatibility of the gold dinar with the Maqasid. Humanomics, 22(2), 84-97.

Kothari, C. (2004). Research Methodology: Methods and Techniques (second revised edition). New Age International (P) Limited.

Lewis, M. K. (2001). Islam and Accounting. Accounting Forum, 25(2), 103-127.

Lubis, S. K. (2000). Zakat Dalam Perekonomian Modern (Edisi 1 Ce). Sinar Grafika.

Majid, A. M. (1997). Sejarah Kebudayaan Islam. Bandung: Pustaka. Pustaka.

Majid, M. Z. A. (2003). Pengurusan Zakat. Dewan Bahasa dan Pustaka.

Mas'udi, M. F. (1993). Agama Keadilan : Risalah Zakat (Pajak) Dalam ISLAM. P3M.

Mulawarman, A. D., Triyuwono, I., Irianto, G., \& Ludigdo, U. (2011). Menuju Teori Akuntansi Syariah Baru. Jurnal Ekonomi Dan Keuangan Islam, 1(1), 61-78.

Obaidullah, M. (2016). Revisiting Estimation Methods of Business Zakat and Related Tax Incentives. Journal of Islamic Accounting and Business Research, 7(4), 349-364.

Owoyemi, M. Y. (2020). Zakat management: The crisis of confidence in zakat agencies and the legality of giving zakat directly to the poor. Journal of Islamic Accounting and Business Research, 11(2), 498-510. https://doi.org/10.1108/JIABR-07-2017-0097

Purwanto, A., \& Sukmono, D. A. (2009). Panduan Praktis Menghitung Zakat. Sketsa.

Qahf, M. M. (2009). The Islamic economy: analytical of the functioning of the Islamic economic system. Muslim Students Association of U.S. and Canada.

Qaradawi, Y. (2014). Fiqh Al-Zakāh : Dirāsah Muqāranah Li-Ahkāmihā Wa-Falsafatihā Fì Daw' Al-Qurān Wa-Al- 
Sunnah. Risalah Publishing.

Qudamah, A. A. I. A. I. (1986). Al Mughni. Dar hajar.

Rahim, A. R. A. (2003). Zakat on Business Wealth in Malaysia: Corporate Tax Rebate, Accountability, and Governance. Institut Kefahaman Islam Malaysia Journal, 11(1), 37-50.

Rahman, S. (2015). Zakat on retirement and pension plans. International Journal of Islamic and Middle Eastern Finance and Management, 8(3), 274-290.

Saad, R. A. J., Farouk, A. U., \& Abdul Kadir, D. (2020). Business zakat compliance behavioral intention in a developing country. Journal of Islamic Accounting and Business Research, 11(2), 511-530. https://doi.org/10.1108/JIABR-03-2018-0036

Sabiq, S. (2006). Fiqih Sunnah. Pena Pundi Aksara.

Sahata, H. (2003). Kaedah Agihan Zakat Harta: Pengertian, Sistem Dan Agihannya. Pustaka Al-Shafa.

Salam, A. U. al-Q. Bin. (1991). Kitab al-Amwal. Pakistan Hijra Council.

Tariqi, A. A. H. Al. (2004). Ekonomi Islam Prinsip Dasar dan Tujuan (M. I. Syofwani (ed.); ke 1). Magistra Insania Press.

Wiyono, S. (2005). Cara Mudah Memahami Akuntansi Perbankan Syariah: Berdasarkan PSAK Dan PAPSI. Grasindo.

Zaidi, A. H. (2006). Muslim Reconstructions of Knowledge and the Re-enchantment of Modernity. Theory Cultural Society, 23(5), 69-91.

Zuhaily, W. (2007). Mu'amalat al-Maliyah al-Mu'asirah. Dar Al- Fikr. 